\title{
DUSKY ALBATROSS.
}

\author{
†iomedea fusca, Aud. \\ PLATE CCCCLIV.-Adult.
}

The skin from which I made my drawing of this species was prepared by Mr. Townsend, who procured the bird near the mouth of the Columbia river. Of its habits or distribution I am entirely ignorant. Having failed in finding any figure or description of an Albatross agreeing entirely with it, I have been induced to consider it as new.

Dusky Albatross, Diomedea fusca, Aud. Orn. Biog., vol. v. p. 116.

Adult-length, 34; wing, 21; tail, 11; bill, $4 \frac{1}{1} \frac{0}{2}$.

Off the Columbia river.

Adult.

Bill longer than the head, nearly straight, stout, much compressed. Upper mandible with its dorsal outline straight and declinate until about one-third of its length, when it becomes a little concave, and along the unguis curves in the third of a circle, the ridge narrow, pointed at the base, separated in its whole length by a groove margined below by a prominent line from the sides, which are erect and convex, the edges sharp, the unguis decurved, strong, and sharp. Nostrils sub-basal, prominent, tubular, having a horny sheath, and placed rather nearer the ridge than the margin. Lower mandible with the angle narrow, reaching to the tip, and having at its extremity a slender interposed process; the outline of the crura gently ascending, and nearly straight, towards the end a little deflected, the sides ascending and a little convex, with a groove in their whole length as far as the unguis, filled by a membrane, which is wider at the base, the edges sharp, the tip compressed, its upper edges decurved.

Head rather large; neck of moderate length, body full. Feet rather short, stoutish; tibia bare for an inch, covered all round with small angular scales; toes three, long, slender, the two outer a little shorter than the middle, the inner considerably shorter; they are covered above with small angular scales at the base, in the rest of their extent with scutella, and connected by emarginate webs, the outer and inner with an external membrane. Claws 
है

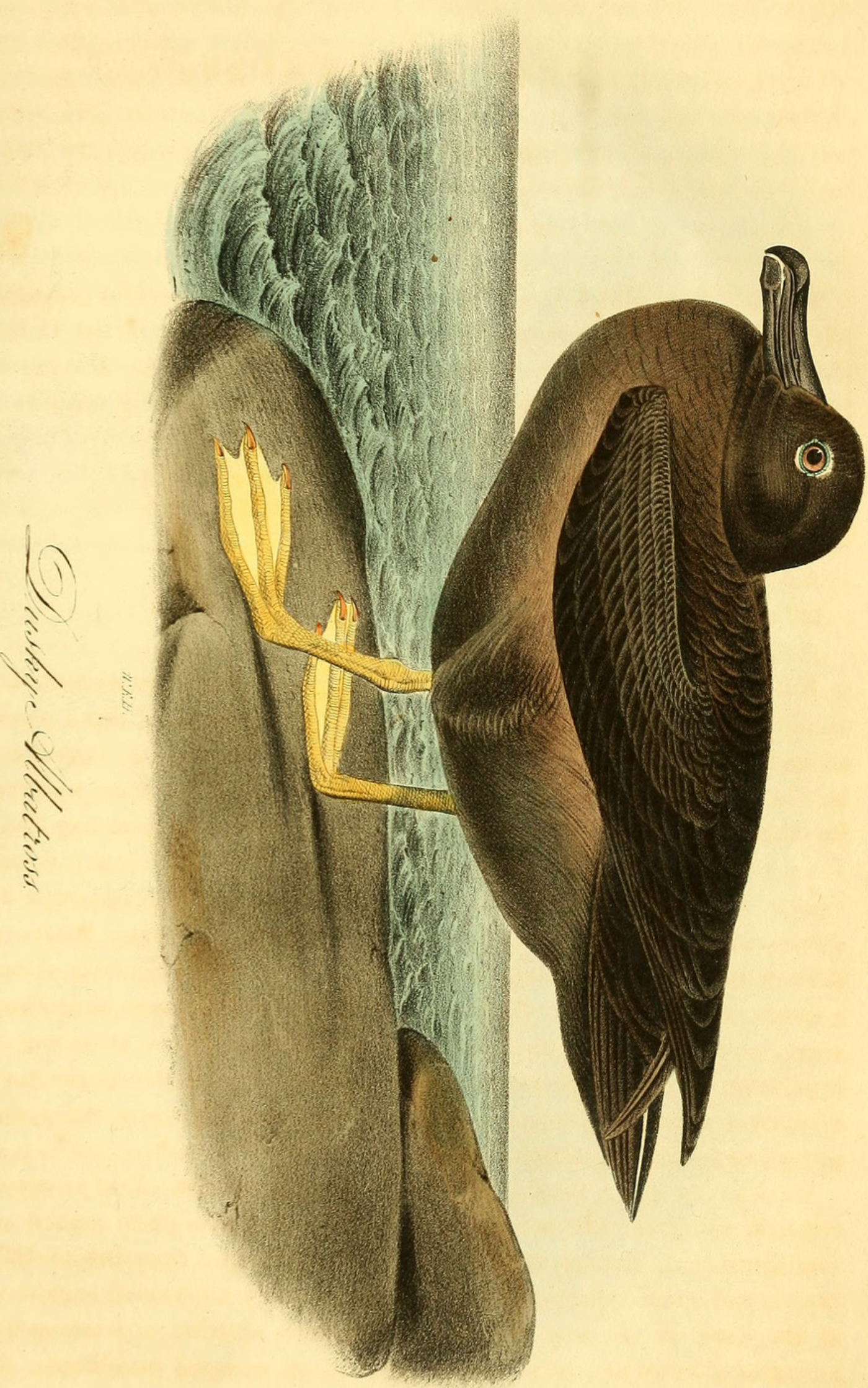

ही

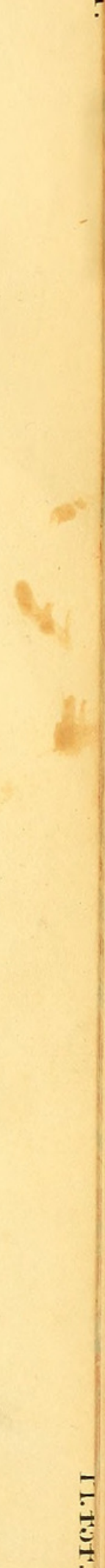




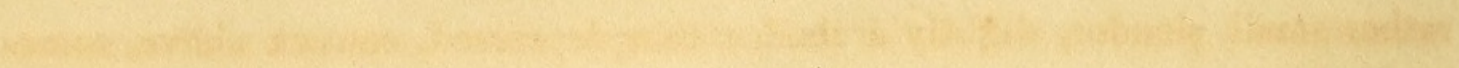

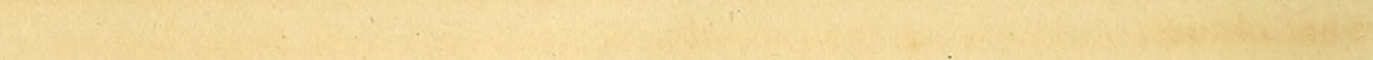

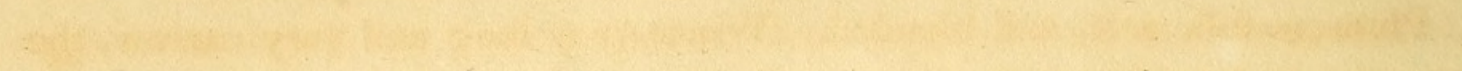

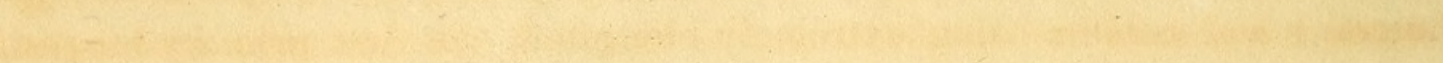

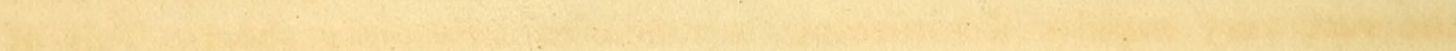

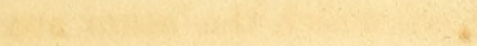


rather small, slender, slightly arched, rather depressed, convex above, somewhat obtuse.

Plumage full, soft, and blended. Wings very long and very narrow, the humerus and cubitus being extremely elongated; the first primary longest, the rest very rapidly diminishing; secondaries extremely short. Tail of moderate length, cuneate, of twelve strong feathers, of which the outer are rounded, the inner gradually more acute, the middle feather exceeding the lateral by two inches and three-fourths.

Bill black; feet yellow, claws greyish-white. The head and upper part of the neck are greyish-black, tinged with brown; the rest of the neck, all the lower parts, the back and rump are light brownish-grey; the scapulars darker, the wings coloured like the head; the primary quills and tail-feathers greyish-black, with white shafts. The eyelids are narrowly margined with white feathers, their anterior part excepted.

Length to end of tail 34 inches; bill along the ridge $4 \frac{1}{1} \frac{0}{2}$, along the edge of lower mandible $3 \frac{5}{12}$; wing from flexure 21 ; tail 11 ; bare part of tibia 1 ; tarsus $3 \frac{2}{12}$; inner toe $3 \frac{7 \frac{1}{2}}{2}$, its claw $\frac{6 \frac{1}{2}}{12}$; middle toe $4 \frac{4 \frac{1}{2}}{12}$, its claw $\frac{9}{12}$; outer toe $4 \frac{3 \frac{1}{2}}{12}$, its claw $\frac{7}{12}$.

\section{Genus III.-PROCELLARIA, Linn. FULMAR.}

Bill of about the length of the head, or somewhat shorter, robust, straight, moderately compressed, with the tip decurved; upper mandible with the nostrils dorsal, separated by a thin septum, covered by an elevated horny case, and opening directly forwards, the ridge nearly straight or concave in its outline, laterally sloping or convex, separated by a groove from the sides, which are erect and convex, the edges sharp, inflected, and in their outline slightly recurved from the base to the unguis, which is strong, decurved, and acute; lower mandible with the angle long, narrow, acute, the sides erect, with a groove in their whole length, the edges sharp and direct, the very short dorsal line ascending and slightly concave, the edges decurved at the end. Head rather large, ovate; neck rather short; body full. Feet of moderate length, stout; tibia bare for a short space below; tarsus a little

VOL. VII. 
compressed, reticulated with angular scales; hind toe a slight prominence with a conical claw; fore toes long, slender, scutellate, connected by striated even webs; fourth toe slightly shorter than third. Claws moderate, arched, compressed, rather acute. Plumage full, close, elastic, rather compact above. Wings very long, narrow, the first quill longest. Tail short, or of moderate length, of from twelve to sixteen feathers.

\title{
G I G A N T I C F U L M A R.
}

\author{
+Procellaria gigantea, Linn.
}

(NOT FIGURED.)

A specimen of the Gigantic Fulmar, shot at some distance from the mouth of the Columbia river, has been sent to me by Mr. Townsend, along with those of other species of the same genus described in this volume, and which it resembles in form and proportions. The great size of this bird gives it at first sight the appearance of an Albatross. It is described as frequent in the southern seas, gliding silently over the surface of the waters, and subsisting on carcasses of cetacea, seals, birds, and other animal matter; the sailors distinguishing them by the name of "Mother Carey's Geese."

Gigantic Fulmar, Procellaria gigantea, Aud. Orn. Biog., vol. v. p. 330.

Length, 36; tail, $7 \frac{1}{2}$; bill, 4.

Off the Columbia river.

Bill longer than the head, robust, straight, moderately compressed, with the tip decurved. Upper mandible with the nostrils on the ridge, separated only by a thin septum, covered by a broad elongated horny case, of which the ridge is nearly straight and carinate, and the base striated; the sides erect and convex, separated by a groove from the nasal plate, as well as from the unguis, which is remarkably strong, curved, laterally convex, and acute, the edges blunt, direct, slightly recurved, along the unguis sharp and decurved. Lower mandible with the angle long and narrow, the sides sloping a little outwards and nearly flat, with a longitudinal seam near the edges, 
है

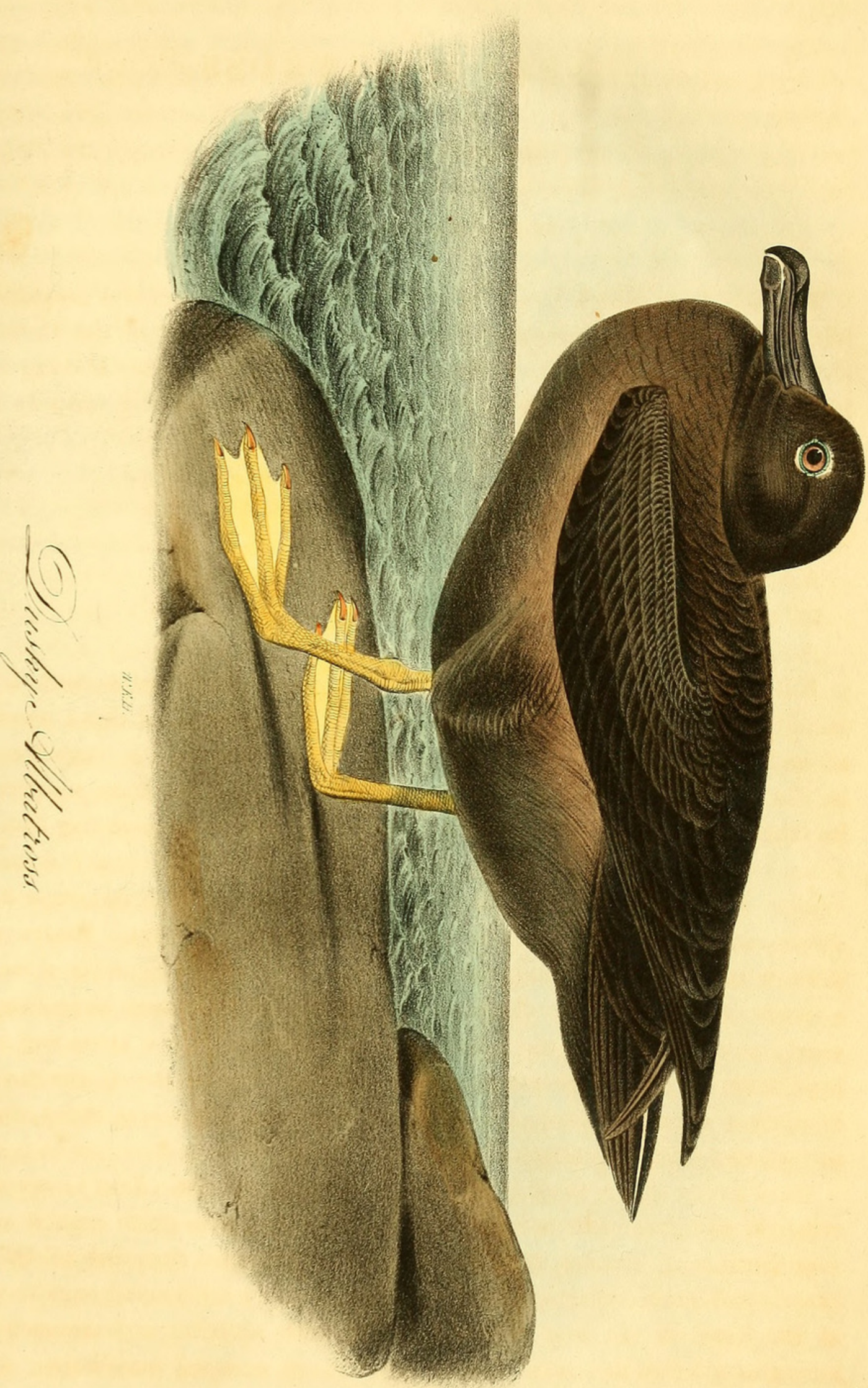

ही

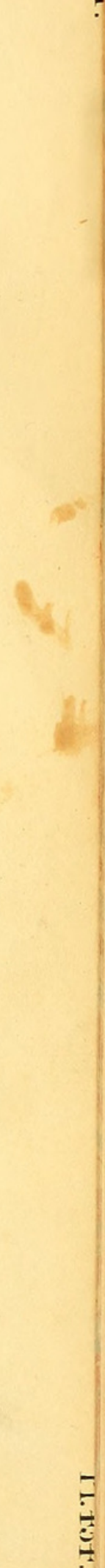




\section{$2 \mathrm{BHL}$ Biodiversity Heritage Library}

Audubon, John James. 1844. "Dusky Albatross, Diomedea fusca, Aud. [PI. 454]." The birds of America : from drawings made in the United States and their territories 7, 200-202. https://doi.org/10.5962/p.319568.

View This Item Online: https://www.biodiversitylibrary.org/item/124981

DOI: https://doi.org/10.5962/p.319568

Permalink: https://www.biodiversitylibrary.org/partpdf/319568

\section{Holding Institution}

Smithsonian Libraries

\section{Sponsored by}

Biodiversity Heritage Library

\section{Copyright \& Reuse}

Copyright Status: NOT_IN_COPYRIGHT

This document was created from content at the Biodiversity Heritage Library, the world's largest open access digital library for biodiversity literature and archives. Visit BHL at https://www.biodiversitylibrary.org. 